\title{
Repeatability coefficients and genetic gains in table grape progenies for the Brazilian semi-arid region
}

\author{
Patrícia Coelho de Souza Leão ${ }^{1 *}$, Bruna Thaís Gonçalves Nunes² Emille Mayara Carvalho de Souza² $^{2}$
}

${ }^{1}$ Embrapa Semi-Arid, BR 428, km 152 - 56302-970 -

Petrolina, PE - Brazil.

${ }^{2}$ State University of Pernambuco - Dept. of Biology, Av. Cardoso de Sá, 710 - 56328-020 - Petrolina, PE - Brazil.

*Corresponding author < patricia.leao@embrapa.br>

Edited by: Leonardo Oliveira Medici

Received February 06, 2017

Accepted June 11, 2017

\begin{abstract}
Table grape stands out among the main fruit-bearing plants of irrigated agriculture in the São Francisco Valley region of Brazil. This study estimated repeatability and heritability coefficients and predicted genetic gains in order to select superior genotypes in grape progenies from controlled hybridizations using the Restricted Maximum Likelihood/Best Linear Unbiased Prediction (REML/BLUP) methodology. Individual plants were evaluated for the variables of production (kg per plant), number of bunches, bunch weight $(\mathrm{g})$, berry diameter $(\mathrm{mm})$, and soluble solids content ('Brix). We evaluated 194 hybrids from 30 crosses between Vitis vinifera and interspecific hybrids in Juazeiro, Bahia State, Brazil, over four growing seasons. Repeatability coefficients, ranging from 0.164 for soluble solids content to 0.72 for berry diameter, were estimated with accuracy values higher than $80 \%$ for all variables, except for soluble solids content $(66 \%)$. The 30 best individuals classified for each variable exhibited genetic gains and their new estimated mean values were higher than the overall mean of the population in all variables. Regarding production and number of bunches per plant as the main variables, 15 genotypes were selected simultaneously for both variables. Among which, hybrids CPATSA 15.05, 15.06, 15.06T, and 23.103 stand out because they have trace seeds and should be selected for the following steps of genetic breeding to develop new table grape cultivars for the Brazilian semiarid region.

Keywords: Vitis sp., REML/BLUP, grapevine, grape breeding
\end{abstract}

\section{Introduction}

Table grape accounts for $48 \%$ of Brazilian grape production and São Francisco Valley region is the main producing region of Vitis vinifera grapes, covering an area of 9,703 ha harvested and a production of 315,338 tons in 2015 (Agrianual, 2016). However, the main table grape cultivars show adaptation difficulties to tropical climate, underscoring the importance of better-adapted cultivars.

Hybridizations is the classical method of breeding seedless table grape, comprising the following steps: a) selection of parents; b) controlled hybridizations; c) immature embryos in vitro; d) acclimatization and planting in the field; e) agronomic evaluations and selection, and f) validation trials in commercial companies (Leão and Borges, 2013).

In mass selection, plants are chosen by their phenotypic values because there are no repetitions in this phase. In the first selection phase of grape, each genotype is represented by one plant in a single environment. Thus, evaluation is based on variables correlated with grape production and quality. Therefore, selection efficiency depends on the amount of variability in the base population, heritability of the trait desired in breeding, and the extent of genetic gain of the trait selected.

In breeding perennial species, the use of genetic evaluation techniques based on mixed models, such as REML/BLUP, is fundamental to predict additive genetic values and genotypic values of individuals with potential for selection at the intra and interpopulational levels (Resende, 2007).
This methodology has been widely used to estimate genetic parameters, select progenies, adaptability and stability. It is also used in breeding programs of perennial species, such as bacuri (Maia et al., 2016a), cajuí (small cashew) (Maia et al., 2016b), baru (Santos et al., 2014), Brazil nut (Pedrozo et al., 2015), passion fruit (Santos et al., 2015; Freitas et al., 2016; Silva et al., 2016), coffee (Rodrigues et al., 2013), peach (Bruna et al., 2012), and others. Nevertheless, references in the literature were not found regarding the use of this method in grape breeding.

This study aimed to estimate genetic and phenotypic parameters and predict genetic values of grape hybrids through the REML/BLUP methodology to select superior individuals and breed them to develop new table grape cultivars for the Brazilian semi-arid region.

\section{Materials and Methods}

The experiment was carried out in Juazeiro, Bahia State, Brazil, at $9^{\circ} 24^{\prime} \mathrm{S}, 40^{\circ} 26^{\prime} \mathrm{W}$, and $365.5 \mathrm{~m}$ a.s.l. The climate is Bswh according Koppen classification (Alvares et al, 2013), hot semi-arid with average annual rainfall $505 \mathrm{~mm}$, annual average relative humidity $61 \%$, and average, maximum, and minimum annual temperatures of $27{ }^{\circ} \mathrm{C}, 32{ }^{\circ} \mathrm{C}$, and $21{ }^{\circ} \mathrm{C}$, respectively (http://www. cpatsa.embrapa.br:8080/servicos/dadosmet/cem-anual. html). The soil in the experimental area is classified as Vertisol.

The treatments comprised 194 progenies, derived from 30 crosses between cultivars of Vitis vinifera spe- 
cies, between interspecific hybrids (complex hybrids of different Vitis species), also between Vitis vinifera and interspecific hybrids. F1 progenies (each vine, one genotype) were established in a trial with no experimental design and evaluated during four growing seasons from 2010-2014. The vines were grafted onto rootstock IAC 572 using the trellis training system at spacing $3 \times 2 \mathrm{~m}$ and drip irrigation. The size of progenies ranged from one to 37 hybrid genotypes. The codes and parents of 24 best progenies are shown in Table 1.
Among 13 quantitative variables evaluated, five were used in this study because of their importance for table grape breeding programs: production (kg per plant), obtained by weighing all the grape bunches at harvest time; number of bunches per plant, by counting bunches on the plant before harvest; bunch weight (g), the ratio between production weight and the number of bunches harvested; berry diameter ( $\mathrm{mm})$, determined in a sample of 10 berries per bunch with the aid of a ruler; and total soluble solids content $\left({ }^{\circ} \mathrm{Brix}\right)$,

Table 1 - Parent cultivars, species, number of individuals (\#ind), individuals (Ind), corresponding hybrid codes (codes) of 30 grape progenies.

\begin{tabular}{|c|c|c|c|c|}
\hline Parent Cultivars & Species & \#Ind & Ind & Codes \\
\hline Moscatel Nazareno $\times$ Thompson & V. vinifera $\times$ V.vinifera & 5 & $1-5$ & $01.01,01.03,01.04,01.08,01.09$ \\
\hline A1118 $\times$ Thompson & Hybrid $\times$ V.vinifera & 6 & 6-11 & $02.06,02.11,02.14,02.22,02.26,02.27$ \\
\hline A $1118 \times$ Marroo & Hybrid $\times$ Hybrid & 2 & $12-13$ & $03.03,03.10$ \\
\hline Burdin $\times$ Thompson & Hybrid $\times$ V.vinifera & 4 & $14-17$ & $04.01,04.06,04.09,04.11$ \\
\hline Ferlongo $\times$ Marroo & V. vinifera $\times$ Hybrid & 8 & $18-25$ & $05.01,05.02,05.03,05.04,05.06,05.07,05.09,05.12$ \\
\hline A $1118 \times$ Sugraone & Hybrid $\times$ V.vinifera & 2 & $26-27$ & $06.40,06.90$ \\
\hline Moscatel Nazareno $\times$ Feal & V. vinifera $\times$ V.vinifera & 1 & 28 & 07.02 \\
\hline A Dona $\times$ Jupiter & Hybrid $\times$ Hybrid & 2 & $29-30$ & $08.01,08.02$ \\
\hline Moscatel Alexandria $\times$ Catalunha & V. vinifera $\times$ V.vinifera & 1 & 31 & 09.02 \\
\hline Ferlongo $\times$ Sugraone & V. vinifera $\times$ V.vinifera & 3 & $32-34$ & $11.01,11.02,11.03$ \\
\hline Moscatel Alexandria $\times$ Catalunha & V. vinifera $\times$ V.vinifera & 1 & 35 & 13.01 \\
\hline Sugraone $\times$ Thompson & V. vinifera $\times$ V.vinifera & 14 & $36-49$ & $\begin{array}{l}\text { 14.01, 14.02, 14.03CR, 14.04, 14.05, 14.05G, 14.05T, 14.07T } \\
14.08 \mathrm{G}, 14.10 \mathrm{G}, 14.14 \mathrm{G}, 14.23 \mathrm{G}, 14.25 \mathrm{G}, 14.27 \mathrm{G}\end{array}$ \\
\hline Sugraone $\times$ Marroo & V. vinifera $\times$ Hybrid & 8 & $50-57$ & 15.02T, 15.03T, 15.04, 15.04T, 15.05, 15.05T, 15.06, 15.06T \\
\hline Seyve Villar 20365 × Caralunha & Hybrid $\times$ V.vinifera & 3 & $58-60$ & $16.16,16.26,16.36$ \\
\hline Moscatel Hamburgo $\times$ Sugraone & V. vinifera $\times$ V.vinifera & 3 & $61-63$ & $17.01,17.06,17.07$ \\
\hline Baresana $\times$ Sugraone & V. vinifera $\times$ V.vinifera & 8 & $64-71$ & $18.01,18.07,18.13,18.17,18.31,18.33,18.35,18.38$ \\
\hline Moscatel Alexandria $\times$ Sugraone & V. vinifera $\times$ V.vinifera & 3 & $72-74$ & $19.02,19.10,19.16$ \\
\hline Branca Salitre $\times$ Catalunha & V. vinifera $\times$ V.vinifera & 24 & $75-98$ & $\begin{array}{l}20.01,20.02,20.03,20.07,20.104,20.13,20.16,20.18,20.20 \\
\begin{array}{l}20.22,20.24,20.29,20.31,20.32,20.34,20.36,20.37,20.40 \\
20.42,20.52,20.58,20.59,20.60,20.61\end{array}\end{array}$ \\
\hline Moscato Noir $\times$ Crimson & V. vinifera $\times$ V.vinifera & 27 & $99-126$ & $\begin{array}{l}21.01,21.07,21.09,21.101,21.106,21.109,21.111,21.14 \\
21.20,21.32,21.41,21.42,21.48,21.49,21.50,21.57,21.58 \\
21.59,21.62,21.64,21.67,21.73,21.88,21.89,21.93,21.96 \\
21.98,21.99\end{array}$ \\
\hline Ferlongo $\times$ Crimson & V. vinifera $\times$ V.vinifera & 10 & $127-136$ & $\begin{array}{l}22.07,22.19,22.31,22.36,22.55,22.59,22.60,22.64,22.67 \text {, } \\
22.71\end{array}$ \\
\hline Burdin $\times$ Marroo & Hybrid $\times$ Hybrid & 3 & $137-139$ & $23.08,23.09,23.103$ \\
\hline Ferlongo $\times$ Catalunha & V. vinifera $\times$ V.vinifera & 1 & 140 & 26.03 \\
\hline Stover $\times$ Marroo & Hybrid $\times$ Hybrid & 1 & 141 & 34.01 \\
\hline Italia $\times$ Thompson & V. vinifera $\times$ V.vinifera & 1 & 142 & 39.16 \\
\hline Feal $\times$ Catalunha & V. vinifera $\times$ V.vinifera & 6 & $143-148$ & 40.02T, 40.03І, 40.03T, 40.04T, 40.10T, 40.13T \\
\hline Sugraone $\times$ Catalunha & V. vinifera $\times$ V.vinifera & 38 & $149-186$ & $\begin{array}{l}\text { 42.00G, 42.00T, 42.02T, 42.03G, 42.04, 42.04G, 42.04I, 42.05, } \\
\text { 42.05G, 42.06G, 42.06T, 42.07, 42.10G, 42.10ID, 42.100T, 42.101 } \\
\text { I, 42.101T, 42.103, 42.103T, 42.11G, 42.124T, 42.13G, 42.14T, } \\
\text { 42.144T, 42.15 T, 42.16, 42.18G, 42.18I, 42.19G, 42.20G,42.21, } \\
\text { 42.22G, 42.23G,42.31G, 42.33G, 42.35G,42.96, 42.97T }\end{array}$ \\
\hline Sufolk Red Seedless $\times$ Thompson & Hybrid $\times$ V.vinifera & 2 & $187-188$ & $51.29,51.68$ \\
\hline Sugraone $\times$ CG38049 & V. vinifera $\times$ V.vinifera & 1 & 189 & 53.03 \\
\hline Jupiter $\times$ Grenache & Hybrid $\times$ V.vinifera & 2 & $190-191$ & $60.34,60.36$ \\
\hline CG $351 \times$ Thompson & V. vinifera $\times$ V.vinifera & 1 & 192 & 61.25 \\
\hline Seyve Villar $12375 \times$ Sugraone & Hybrid $\times$ V.vinifera & 1 & 193 & 68.06 \\
\hline
\end{tabular}


determined in an Abbe benchtop digital refractometer (AOAC, 1992). The harvest time for each growing season was determined when soluble solids content was $15^{\circ}$ Brix at minimum.

The estimates of variance components and genetic parameters were obtained by the mixed linear models methodology (residual or restricted maximum likelihood/best linear unbiased prediction) using the genetic-statistical computational application SELEGEN - REML/BLUP and the basic model of repeatability that assumes absence of design. This may be written in the matrix form through the following equation (Resende and Duarte, 2007): $\mathrm{y}=\mathrm{Xm}+\mathrm{Zp}+\mathrm{e}$, in which $\mathrm{y}$ is the vector of the variable to be analyzed; $\mathrm{m}$ is the vector of effects of measurements assumed as fixed and added to the overall mean; $p$ is the vector of permanent phenotypic effects (genotype effects + permanent environment effects) assumed as random; e is the vector of random errors; $X$ is the incidence matrix for the fixed effects; and $\mathrm{Z}$ is the incidence matrix for the permanent phenotypic effects.

The following variance components were estimated: Vfp - permanent phenotypic variance among plants (genotypic + permanent environmental from one har- vest to another); Vet - temporary environmental variance; Vf - individual phenotypic variance; $r=h 2-$ individual repeatability; $\mathrm{rm}$ - repeatability of the mean of $\mathrm{m}$ harvests or repeated measures; and $\mathrm{A}_{\mathrm{cm}}$ - selection accuracy based on the mean of $m$ harvests or repeated measures (Table 2).

The coefficient of determination $(\mathrm{C})$ and accuracy with the $\mathrm{m}$ repeated measures $(\mathrm{Acm})$ were also obtained, as well as the efficiency of the measurement (Ef) performed in comparison when only one measurement was used (Table 3).

This simulation of genetic gains was performed using a $16 \%$ selection intensity for each variable analyzed, which corresponds to 30 best individuals in a sample of 194 hybrids at the level of individuals (Table 4).

\section{Results and Discussion}

The estimates of variance components and phenotypic parameters for the variables considered in this study are shown in Table 2.

The overall production average was $7.81 \mathrm{~kg}$ per plant, corresponding to estimated yield of $13 \mathrm{t} \mathrm{ha}^{-1}$ per growing season, considered low yield compared to the

Table 2 - Estimates of variance components (individual REML) for traits of production, number of bunches per plant, bunch weight, berry diameter and soluble solids content ('Brix) obtained from 194 hybrid genotypes, Juazeiro, BA, Brazil.

\begin{tabular}{|c|c|c|c|c|c|}
\hline Variance component $^{1}$ & Production & Number of bunches & Bunch weight & Berry diameter & Soluble solids \\
\hline & kg per plant & & $\mathrm{g}$ & $\mathrm{mm}$ & ${ }^{\circ}$ Brix \\
\hline Vfp & 27.63 & 1072.15 & 8486.19 & 2.72 & 0.95 \\
\hline Vet & 24.52 & 701.38 & 12050.19 & 1.09 & 4.84 \\
\hline Vf & 52.15 & 1773.53 & 20536.38 & 3.81 & 5.79 \\
\hline $\mathrm{R}=\mathrm{h} 2$ & $0.53 \pm 0.07$ & $0.60 \pm 0.08$ & $0.41 \pm 0.07$ & $0.72 \pm 0.09$ & $0.164 \pm 0.04$ \\
\hline $\mathrm{Rm}$ & 0.82 & 0.86 & 0.74 & 0.91 & 0.44 \\
\hline$A_{c m}$ & 0.91 & 0.93 & 0.86 & 0.95 & 0.66 \\
\hline Overall mean & 7.81 & 39.41 & 334.33 & 17.47 & 17.13 \\
\hline
\end{tabular}

${ }^{1} \mathrm{Vfp}=$ permanent phenotypic variance among plants (genotypic + permanent environmental from one harvest to another); Vet = temporary environmental variance; $\mathrm{Vf}$ $=$ individual phenotypic variance; $\mathrm{R}=\mathrm{h} 2=$ individual repeatability; $\mathrm{Rm}=$ repeatability of the mean of $\mathrm{m}$ harvests or repeated measures; $\mathrm{A}_{\mathrm{cm}}=$ accuracy of selection based on the mean of $m$ harvests or repeated measures.

Table 3 - Coefficients of determination $(C)$, precision of permanent phenotypic values based on $m$ measures repeated $\left(A_{c m}\right)$ (growing seasons) and efficiency of measurements $m$ in comparison to when only one evaluation is made $\left(E_{f}\right)$, for the variables of production, number of bunches, bunch weight, berry diameter, and soluble solids content.

\begin{tabular}{|c|c|c|c|c|c|c|c|c|c|c|c|c|c|c|c|}
\hline \multirow{3}{*}{$\begin{array}{l}\text { Growing season } \\
\text { (m) }\end{array}$} & \multirow{2}{*}{\multicolumn{3}{|c|}{\begin{tabular}{|l} 
Production \\
kg per plant
\end{tabular}}} & \multirow{2}{*}{\multicolumn{3}{|c|}{ Number of bunches }} & \multicolumn{3}{|c|}{ Bunch weight } & \multicolumn{3}{|c|}{ Berry diameter } & \multicolumn{3}{|c|}{ Soluble solids } \\
\hline & & & & & & & \multicolumn{3}{|c|}{$\mathrm{g}$} & \multicolumn{3}{|c|}{$\mathrm{mm}$} & \multicolumn{3}{|c|}{${ }^{\circ}$ Brix } \\
\hline & C & $A_{c m}$ & $E_{f}$ & $\mathrm{C}$ & $A_{c m}$ & $E_{f}$ & $\mathrm{C}$ & $A_{c m}$ & $E_{f}$ & $C$ & $A_{c m}$ & $E_{f}$ & $C$ & $A_{c m}$ & $E_{f}$ \\
\hline 1 & 0.53 & 0.73 & 1.00 & 0.60 & 0.78 & 1.00 & 0.41 & 0.64 & 1.00 & 0.72 & 0.85 & 1.00 & 0.16 & 0.41 & 1.00 \\
\hline 2 & 0.69 & 0.83 & 1.14 & 0.75 & 0.87 & 1.12 & 0.58 & 0.76 & 1.19 & 0.83 & 0.91 & 1.08 & 0.28 & 0.53 & 1.31 \\
\hline 3 & 0.77 & 0.88 & 1.21 & 0.82 & 0.91 & 1.17 & 0.68 & 0.82 & 1.28 & 0.88 & 0.94 & 1.11 & 0.37 & 0.61 & 1.50 \\
\hline 4 & 0.82 & 0.90 & 1.24 & 0.86 & 0.93 & 1.19 & 0.74 & 0.86 & 1.34 & 0.91 & 0.95 & 1.13 & 0.44 & 0.66 & 1.64 \\
\hline 5 & 0.85 & 0.92 & 1.27 & 0.88 & 0.94 & 1.21 & 0.78 & 0.88 & 1.37 & 0.93 & 0.96 & 1.14 & 0.50 & 0.70 & 1.74 \\
\hline 6 & 0.87 & 0.93 & 1.28 & 0.90 & 0.95 & 1.22 & 0.81 & 0.90 & 1.40 & 0.94 & 0.97 & 1.15 & 0.54 & 0.74 & 1.82 \\
\hline 7 & 0.89 & 0.94 & 1.29 & 0.91 & 0.96 & 1.23 & 0.83 & 0.91 & 1.42 & 0.95 & 0.97 & 1.15 & 0.58 & 0.76 & 1.88 \\
\hline 8 & 0.90 & 0.95 & 1.30 & 0.92 & 0.96 & 1.24 & 0.85 & 0.92 & 1.43 & 0.95 & 0.98 & 1.15 & 0.61 & 0.78 & 1.93 \\
\hline 9 & 0.91 & 0.95 & 1.31 & 0.93 & 0.97 & 1.24 & 0.86 & 0.93 & 1.45 & 0.96 & 0.98 & 1.16 & 0.64 & 0.80 & 1.97 \\
\hline 10 & 0.92 & 0.96 & 1.32 & 0.94 & 0.97 & 1.25 & 0.88 & 0.94 & 1.46 & 0.96 & 0.98 & 1.16 & 0.66 & 0.81 & 2.01 \\
\hline
\end{tabular}


Table 4 - Genetic gains and new mean values est imated via REML/BLUP with the selection of the 30 best grape hybrids for the variables of production, number of bunches per plant, bunch weight, berry diameter, and soluble solids content. Ord = order; Ind = individual; $\mathrm{N}$ mean = new mean value.

\begin{tabular}{|c|c|c|c|c|c|c|c|c|c|c|c|c|c|c|c|c|c|c|}
\hline \multirow{2}{*}{\multicolumn{4}{|c|}{$\begin{array}{l}\text { Production } \\
\text { kg per plant }\end{array}$}} & \multirow{2}{*}{\multicolumn{3}{|c|}{ Number of bunches }} & \multicolumn{4}{|c|}{ Bunch weight } & \multicolumn{4}{|c|}{ Berry diameter } & \multicolumn{4}{|c|}{ Soluble solids } \\
\hline & & & & & & & \multicolumn{4}{|c|}{$\mathrm{g}$} & \multicolumn{4}{|c|}{$\mathrm{mm}$} & \multicolumn{4}{|c|}{${ }^{\circ}$ Brix } \\
\hline Ord & Ind & Gain & $\mathrm{N}$ mean & Ord Ind & Gain & $\mathrm{N}$ mean & Ord & Ind & Gain & $\mathrm{N}$ mean & Ord & Ind & Gain & $\mathrm{N}$ mean & Ord & Ind & Gain & $\mathrm{N}$ mean \\
\hline 1 & 24 & 24.13 & 31.94 & 124 & 160.79 & 200.20 & 1 & 160 & 211.21 & 545.53 & 1 & 55 & 5.42 & 22.89 & 1 & 125 & 1.70 & 18.83 \\
\hline 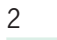 & 20 & 20.70 & 28.51 & 225 & 144.35 & 183.77 & 2 & 5 & 208.84 & 543.17 & 2 & 171 & 4.85 & 22.32 & 2 & 3 & 1.60 & 18.73 \\
\hline 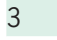 & 21 & 18.18 & 25.99 & 320 & 138.51 & 177.93 & 3 & 55 & 205.56 & 539.88 & 3 & 74 & 4.34 & 21.81 & - & 143 & 1.49 & 18.62 \\
\hline 4 & 18 & 16.87 & 24.68 & 4102 & 131.78 & 171.20 & 4 & 151 & 197.60 & 531.93 & 4 & 189 & 3.99 & & 4 & 168 & 1.42 & 18.55 \\
\hline $\mathrm{J}$ & 137 & 15.66 & 23.47 & 597 & 127.61 & 167.03 & 5 & 190 & 191.16 & 525.49 & 5 & 68 & 3.76 & 2. & ᄃ & 16 & 1.36 & 18.49 \\
\hline 6 & 5 & 14.79 & 22.60 & 6101 & 121.65 & 161.06 & 6 & 163 & 18 & & 6 & 193 & 3.57 & & 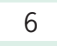 & 179 & .30 & 18.43 \\
\hline & 73 & 14.10 & 21.92 & 723 & 116.10 & 155.51 & 7 & 38 & 178.60 & 512.92 & 7 & 63 & 3.43 & 20.89 & 7 & 100 & 1.26 & 18.39 \\
\hline & 42 & 13.55 & 21.36 & 8100 & 110.30 & 149.71 & 8 & 41 & 17 & 50 & 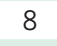 & 16 & 3.31 & 2 & 8 & 180 & .23 & 8.36 \\
\hline 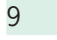 & 52 & 13.10 & 20.91 & 918 & 104.97 & 1 & 9 & 77 & 16 & 50 & 9 & 5 & 3.21 & & J & 22 & 1.20 & 18.33 \\
\hline 10 & 25 & 12.69 & 20.51 & 1056 & 100.71 & 140.13 & 10 & 96 & 165.39 & 499 & 10 & 184 & 3.12 & 20 & 10 & 21 & 1.18 & 18.31 \\
\hline 11 & 15 & 12.34 & 20.15 & 1119 & 96.96 & 136.37 & 11 & 49 & 161.15 & & 11 & 133 & 3.05 & & 1 & 172 & .15 & 18.29 \\
\hline 12 & 54 & 12.03 & 19.84 & 1232 & 93.43 & 132.84 & 12 & 16 & 157.61 & 491 & 12 & 67 & 2.99 & 20 & 12 & 26 & 1.14 & 18.27 \\
\hline 13 & 100 & 11.74 & 55 & 1357 & 90.08 & 129.50 & 13 & 110 & 154 & & 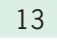 & 137 & .93 & 20. & 3 & 144 & 1.12 & 8.25 \\
\hline 14 & 56 & 11.44 & 19.26 & 1495 & 86.63 & 126.05 & 14 & 192 & 151 & 48 & 14 & 54 & 2.87 & 20 & 14 & 106 & 1.10 & 18.23 \\
\hline 15 & 57 & 11.18 & 18.99 & 1554 & 83.35 & 122.77 & 15 & 97 & 149.48 & 483 & 15 & 186 & 2.83 & 20 & 5 & 140 & 1.09 & 18.22 \\
\hline 16 & 7 & 10.92 & 18.73 & 1640 & 79.95 & 119.36 & 16 & 81 & 147.29 & 481 & 16 & 170 & 2.77 & 4 & 16 & 166 & 1.07 & 18.20 \\
\hline 17 & 4 & 10.68 & 18.49 & 17188 & 76.95 & 116.36 & 17 & 181 & 145 & 47 & 17 & 31 & 2.72 & 20 & 17 & 25 & 1.06 & 18.19 \\
\hline 18 & 1 & 10.46 & 18.28 & 1873 & 74.25 & 113.66 & 18 & 137 & 142.74 & 477.06 & 18 & 105 & 2.68 & 2 & 8 & 10 & 1.05 & 18.18 \\
\hline 19 & 139 & 10.25 & 18.06 & 191 & 71.78 & 111.19 & 19 & 50 & 140.39 & 474 & 19 & 163 & 2.63 & & 19 & 99 & 1.04 & 18.17 \\
\hline 20 & 69 & 10.05 & 17.87 & 20186 & 69.56 & 108.97 & 20 & 102 & 138.27 & 472 & 20 & 1 & 2.60 & 20 & 20 & 122 & 1.03 & 18.16 \\
\hline 21 & 40 & 9.86 & 17.67 & 2196 & 67.44 & 106.85 & 21 & 10 & 136.14 & 470.47 & 21 & 70 & 2.56 & 20.03 & 21 & 79 & 1.02 & 18.15 \\
\hline 22 & 108 & 9.67 & 17.49 & 22129 & 65.45 & 104.86 & 22 & 34 & 134.19 & 468 & 22 & 29 & 2.52 & 19. & 22 & 111 & 1.01 & 18.14 \\
\hline 23 & 178 & 9.50 & 17.31 & 23139 & 63.63 & 103.05 & 23 & 48 & 132.39 & 466.72 & 23 & 122 & 2.49 & 19.96 & 23 & 145 & 1.00 & 18.13 \\
\hline 24 & 189 & 9.34 & 17.15 & 24135 & 61.90 & 101.31 & 24 & 74 & 130.58 & 464.91 & 24 & 181 & 2.46 & 19.92 & 24 & 30 & 0.99 & 18.12 \\
\hline 25 & 112 & 9.18 & 17.00 & 25160 & & & 25 & 40 & 128.85 & & 25 & 8 & 2.43 & 19.89 & 25 & 72 & 0.98 & 18.11 \\
\hline 26 & 163 & 9.04 & 16.85 & 2634 & 58.82 & 98.24 & 26 & 91 & 127.24 & 461.56 & 26 & 26 & 2.39 & 19.86 & 26 & 32 & 0.97 & 18.10 \\
\hline 27 & 19 & 8.91 & 16.72 & $27 \quad 13$ & 57.43 & 96.84 & 27 & 184 & 125.70 & 460.02 & 27 & 23 & 2.36 & 19.83 & 27 & 18 & 0.96 & 18.09 \\
\hline 28 & 37 & 8.76 & 16.57 & 284 & 56.11 & 95.53 & 28 & 23 & 124.20 & 458.53 & 28 & 42 & 2.33 & 19.80 & 28 & 109 & 0.95 & 18.08 \\
\hline 29 & 16 & 8.62 & 16.43 & 2922 & 54.88 & 94.29 & 29 & 86 & 122.81 & 457.13 & 29 & 101 & 2.31 & 19.78 & 29 & 19 & 0.95 & 18.08 \\
\hline 30 & 34 & 8.48 & 16.30 & 30133 & 53.70 & 93.12 & 30 & 164 & 121.50 & 455.83 & 30 & 6 & 2.28 & 19.75 & 30 & 184 & 0.94 & 18.07 \\
\hline Over & nean & & 7.81 & & & 39.41 & & & & 334.33 & & & & 17.47 & & & & 17.13 \\
\hline
\end{tabular}

levels achieved in the São Francisco Valley region by the most recent table grape cultivars released by the Embrapa breeding program, such as $29 \mathrm{t} \mathrm{ha}^{-1}$ for 'BRS Ísis'. However, overall averages for the other variables are within the values expected for table grapes, especially considering cultivars of seedless grape, which generally have bunch weight and berry diameter lower than table grapes with seeds.

The estimated phenotypic variance between plants (Vfp) was greater than the estimated temporary environmental variance (Vet) for the variables of production, number of bunches, and berry diameter, indicating the possibility of success to select genotypes multiplied by vegetative propagation, conserving characteristics of superior genotypes selected. Nevertheless, the higher Vet values compared to Vfp values for the variables of bunch weight and soluble solids indicate that these two variables are highly influenced by environmental conditions, hindering selection of promising genotypes based on simple plant breeding methods, such as clone selection, and others that take into account only the individual phenotype (Pedrozo et al., 2015). Environmental influence on soluble solids content can be explained by the seasonal climate variations in the $1^{\text {st }}$ and $2^{\text {nd }}$ semester crop seasons in the São Francisco Valley.

The individual repeatability coefficients $(R)$ ranged from 0.164 for soluble solids contents to 0.72 for berry diameter. Repeatability coefficients are important for plant breeding, since it is equivalent to the maximum value that broad sense heritability can achieve (Falconer and MacKay, 1996). According to the classification described by Resende (2002), heritability can be considered of low magnitude when $\mathrm{h}^{2} \mathrm{a}<0.15$, average magnitude when $0.15<\mathrm{h}^{2} \mathrm{a}>0.50$, and high magnitude when $\mathrm{h}^{2} \mathrm{a}>0.50$.

Therefore, heritabilities for bunch weight and soluble solids content are of average magnitude, but of high magnitude for production, number of bunches, 
and berry diameter. According to Resende (2007), accuracy values above $90 \%$ are associated to high heritability variables, as observed in this study for the variables of production (0.91), number of bunches (0.93), and berry diameter (0.95). The results show some regularity in repeating the values in the following production cycles, allowing selection of superior genotypes based on few production cycles in these variables. However, the soluble solids content showed lower accuracy values (0.66) associated with lower heritability values. These results are in agreement with Oliveira et al. (2012), who applied mixed models (REML/BLUP) in an F2 segregating population of papaya and found high heritability for fruit diameter and low heritability for soluble solids content. In contrast, high values of heritability for soluble solids content were observed in passion fruit (Santos et al., 2015).

In general, the repeatability values observed in this study were higher than those mentioned for native perennial species such as bacuri (Maia et al., 2016b) and Brazil nut (Pedrozo et al., 2015). However, repeatability coefficients in grape were compatible to those mentioned by Leão and Costa (2003) and Cargnin (2016) for production, number of bunches, and bunch weight, but lower than those for soluble solids content.

Estimates of determination coefficients $(C)$, accuracy of the permanent phenotypic values based on $\mathrm{m}$ measures or growing seasons $\left(\mathrm{A}_{\mathrm{cm}}\right)$, and selection efficiency of $\mathrm{m}$ measures compared to selection based on a single growing season $\left(\mathrm{E}_{\mathrm{f}}\right)$ (Table 3) show that for the variable of production per plant, four growing seasons are necessary to achieve coefficients greater than $80 \%$, whereas for number of bunches and berry diameter, only three and two growing seasons are enough (Table 3). In contrast, for bunch weight, six growing seasons need to be evaluated to achieve determination coefficients greater than $80 \%$. For soluble solids content, very low values of individual repeatability corresponded to the need to evaluate 10 growing seasons to achieve the determination coefficient of $66 \%$. For that variable, the use of indirect selection is recommended, based on the study of correlations between the variable and others of better genetic control.

These results are in agreement with the repeatability coefficients obtained by Leão and Costa (2003) in evaluation of 11 seedless grape cultivars in the São Francisco Valley region, confirming the lower repeatability coefficient for soluble solids content, requiring at least eight growing seasons to achieve a determination coefficient of $90 \%$. Nevertheless, Cargnin (2016) reported a smaller number of evaluations in 'Chardonnay' and 'Cabernet Sauvignon' wine grape cultivars. These variations in the repeatability coefficient refer to differences in experimental conditions and especially in the genetic structure of Vitis vinifera cultivars or of progenies originating from crosses.

The 30 best individuals were selected for all the variables analyzed, representing $15 \%$ of the hybrids evaluated. Genetic gains and new mean values estimat- ed were greater than the overall mean for all the variables (Table 4). High gains were observed for number of bunches (161\%), bunch weight (211\%) and lower genetic gains for production (24\%), berry diameter (5 $\%)$, and soluble solids content $(2 \%)$, considering the first individuals of the order.

Among the 30 best hybrids selected, 15 coincide in the variables of production and number of bunches per plant, two coincide in these two variables and in bunch weight (14.05 and 11.03), four hybrids also coincide for soluble solids content $(05.01,05.02,05.12$, and 21.07), and only one hybrid (15.05) coincides simultaneously for production, number of bunches, and berry diameter.

Individual 24 (hybrid 05.09) stood out as first among the 30 best individuals for production and number of bunches per plant, with genetic gains of $24 \%$ and $161 \%$, respectively, which represented an increase of $24.13 \mathrm{~kg}$ per plant and 161 bunches in relation to the overall mean. Individual 160 (hybrid 42.06T) was the first in terms of bunch weight, achieving gains of $211 \%$ and an addition of $211.20 \mathrm{~g}$ to bunch weight in relation to the overall mean of the population. The genetic structure of the population studied may have favored an increase in the genetic gains in the variables of number of bunches and bunch weight with considerable heterogeneity for these variables, since the more heterogeneous the expression of a trait, the greater the possible gain from selection, because it is based on genetic differences (Vencovsky, 1987). Considering berry diameter, individual 55 (hybrid 15.05T) stood out as first with gain of $5 \%$, which added $5.42 \mathrm{~mm}$ in berry diameter in comparison to the overall mean. In spite of the small genetic gain in this variable, an increase of $5 \mathrm{~mm}$ in berry diameter can be considered a significant increase because table grapes with large berries are attractive to the consumer and are classified for more demanding markets, achieving higher prices. For soluble solids content, individual 125 (hybrid 21.98 ) achieved a gain of only $2 \%$, adding $1.7^{\circ}$ Brix to the overall mean.

Production and number of bunches per plant are the most important variables to select individuals in progenies; therefore, hybrids CPATSA 15.05, 15.06, $15.06 \mathrm{~T}$ and 23.103 stand out. In addition to being among the 30 best in terms of production and number of bunches, these hybrids have only trace seeds and should be selected to develop new seedless table grape cultivars for the Brazilian semi-arid region. These hybrids are propagated asexually by grafting and proceed to the following step of tests in trials with experimental design and validation in different grape farmers in São Francisco Valley region.

The present study allowed selection of superior genotypes with better performance in relation to grape production and other agronomic characteristics of interest for table grape breeding; therefore, the REML/BLUP statistical method was efficient in predicting genetic gains, especially for the variables of bunch weight, number of bunches, and production. 


\section{Conclusions}

Heritabilities of high magnitude were obtained for production, number of bunches, berry diameter, and average magnitude for bunch weight and soluble solids content.

Four production cycles were sufficient to select superior genotypes for the variables of production and number of bunches per plant.

High genetic gains were obtained especially in the variables of bunch weight and number of bunches per plant.

Among the 30 best hybrids, 15 were identified as coinciding simultaneously for production and number of bunches, and four have trace seeds; thus, they should be selected for the following steps of plant breeding programs of table grapes for the Brazilian semi-arid region.

\section{References}

Agrianual. 2016. Yearbook of Brazilian Agriculture = Anuário da Agricultura Brasileira. FNP Consultoria, São Paulo, SP, Brazil (in Portuguese).

Alvares, C.A.; Stape, J.L.; Sentelhas, P.C.; Gonçalves, J.L.M.; Sparovek, G. 2013. Koppen's climate classification map for Brazil. Meteorologische Zeitschrift 22: 711-728.

Association of Official Agricultural Chemists [AOAC]. 1992. Official Methods of Analysis of the Association of the Agricultural Chemists. 11ed. AOAC, Washington, DC, USA.

Cargnin, A. 2016. Repeatability and number of harvest characteristics for selection of clones of grape varieties. Ciência Rural 46: 221-226 (in Portuguese, with abstract in English).

Falconer, D.S.; MacKay, T.F.C. 1996. Introduction to Quantitative Genetics. Longman, London, England.

Freitas, J.C.O.; Viana, A.P.; Santos, E.A.; Paiva, C.L.; Silva, F.H.L.; Souza, M.M. 2016. Sour passion fruit breeding: strategy applied to individual selection in segregating population of Passiflora resistant to Cowpea aphid-born mosaic virus (CABMV). Scientia Horticulturae 211: 241-247.

Leão, P.C.S.; Borges, R.M.E. 2013. Genetic breeding of grapes = Melhoramento genético da videira. p. 247-281. In: Vidal Neto, F.C.; Cavalcanti, J.J.V., eds. Genetic Plant breeding in the Northeast = Melhoramento genético de plantas no nordeste. Embrapa, Brasília, DF, Brazil (in Portuguese).

Leão, P.C.S.; Costa, J.G. 2003. Estimates of repeatability and path coefficients on grapes. Crop Breeding and Applied Biotechnology 3: 231-236.
Maia, M.C.C.; Macedo, L.M.; Vasconcelos, L.F.L.; Aquino, J.P.A.; Oliveira, L.C.; Resende, M.D.V. 2016a. Estimates of genetic parameters using RELM/BLUP for intrapopulational genetic breeding of platonia insignis Mart. Revista Árvore 40: 561-573.

Maia, M.C.C.; Almeida, A.S.; Macedo, L.M.; Resende, M.D.V.; Lacerda, M.N.; Vasconcelos, L.F.L.; Oliveira, L.C. 2016b. Heritability, repeatability, and genetic gains in a improvement population of cajuízeiro. Revista Árvore 40: 715-722.

Oliveira, E.J.; Fraife-Filho, G.A.; Freitas, J.P.X.; Dantas, J.L.L.; Resende, M.D.V. 2012. Plant selection in F2 segregating populations of papaya from commercial hybrids. Crop Breeding and Applied Biotechnology 12: 191-198.

Pedrozo, C.A.; Tonini, H.; Resende, M.D.V.; Jordão, S.M.S. 2015. Repeatability of fruits and seeds production and selection of Brazil nut genotypes in native populations in Roraima. Revista Árvore 39: 863-871.

Resende, M.D.V. 2002. Biometric and Statistical Genetics in Perennial Plant Breeding = Genética Biométrica e Estatística no Melhoramento de Plantas Perenes. Embrapa Informação Tecnológica, Brasília, DF, Brazil (in Portuguese).

Resende, M.D.V. 2007. SELEGEN-REML/BLUP: Statistical System and Computerized Genetic Selection via Mixed Linear Models = SELEGEN-REML/BLUP: Sistema Estatístico e Seleção Genética Computadorizada via Modelos Lineares Misto. Embrapa Florestas, Colombo, PR, Brazil (in Portuguese).

Rodrigues, W.P.; Vieira, H.D.; Barbosa, D.H.S.G.; Souza Filho, G.R.; Candido, L.S. 2013. Adaptability and genotypic stability of Coffea arabica genotypes based on REML/BLUP analysis in Rio de Janeiro state, Brazil. Genetics and Molecular Research 12: 2391-2399.

Santos, A.M.; Rosado, S.C.S.; Oliveira, A.N. 2014. Estimation of genetic parameters and verification of early selection efficiency in baru (Dipteryx alata). Crop Breeding and Applied Biotechnology 14: 238-243.

Santos, E.A.; Viana, A.P.; Freitas, J.C.O.; Rodrigues, D.L.; Tavares, R.F.; Paiva, C.L.; Souza, M.M. 2015. Genotype selection by REML/BLUP methodology in a segregating population from an interspecific Passiflora spp. crossing. Euphytica 204: 1-11.

Silva, F.H.L.; Munoz, P.R.; Vincent, C.I.; Viana, A.P. 2016. Generating relevant information for breeding Passiflora edulis: genetic parameters and population structure. Euphytica 208: 609-619.

Vencovsky, R. 1987. Quantitative inheritance = Herança quantitativa. p. 137-214. In: Paterniani, E.; Viegas, G.P., eds. Improvement and production of corn. = Melhoramento e produção de milho. 2ed. Fundação Cargill, Campinas, SP, Brazil (in Portuguese). 